\title{
Prospects and Development of Research of Composite Elastomer Materials
}

\author{
Bekhzod B. Yoqubov*a, Akhmadjon Ibadullaev ${ }^{b}$, \\ Dilnora Q. Yoqubova ${ }^{a}$ and Elmira U. Teshabaeva ${ }^{b}$ \\ ${ }^{a}$ Tashkent Chemical-Technological Institute \\ Tashkent, Uzbekistan \\ ${ }^{b}$ Tashkent State Transport University \\ Tashkent, Uzbekistan
}

Received 14.06.2021, received in revised form 22.09.2021, accepted 25.10.2021

\begin{abstract}
The aim of this work is to study the effect of new modified ingredients on the complex of properties of composite elastomeric materials. It was found that the introduction of modified ingredients into the composition of elastomeric compositions enhances interfacial interaction at the «rubber-filler» interface and the formation of additional bonds between rubber macromolecules and functional groups, as a result of which an improvement in the complex of properties of the compositions is observed. The introduction of modified carbon into the composition of elastomeric compositions enhances interfacial interaction at the «rubber-filler» interface and the formation of additional bonds between rubber macromolecules and functional groups of the oligomer, as a result of which an improvement in the complex of properties of the compositions is observed. The technology of purification of mineral fillers from metal oxides has been developed. A sufficiently high degree of purification by this method is due to the fact that in the process of temperature exposure at $950 \mathrm{~K}$, iron ions from the paramagnetic state (d-form $\mathrm{Fe}_{2} \mathrm{O}_{3}$ ) pass into ferromagnetic ( $\mathrm{r}$-form $\mathrm{Fe}_{3} \mathrm{O}_{4}$ ). Feasibility and prospects of using modified fillers, both mineral and organic, in the formulations of rubber compounds for the production of various types of rubber products.
\end{abstract}

Keywords: rubber, filler, plasticizer, accelerator, activator, modification.

Citation: Yoqubov, B. B., Ibadullaev, A., Yoqubova, D. Q., Teshabaeva, E. U. Prospects and development of research of composite elastomer materials, J. Sib. Fed. Univ. Chem., 2021, 14(4), 464-476. DOI: 10.17516/1998-2836-0255

(C) Siberian Federal University. All rights reserved

This work is licensed under a Creative Commons Attribution-NonCommercial 4.0 International License (CC BY-NC 4.0).

* Corresponding author E-mail address: bek-yakubov.93@mail.ru 


\title{
Исследования наполненных композиционных \\ эластомерных материалов
}

\author{
Б. Б. Якубова ${ }^{a}$ А. Ибадуллаев \\ Д.К. Якубова ${ }^{a}$, Э.У. Тешабаева

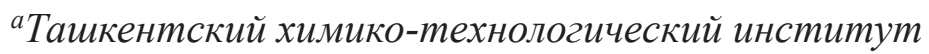 \\ Узбекистан, Ташкент \\ ${ }^{6}$ Ташкентский государственний транспортный университет \\ Узбекистан, Ташкент
}

\begin{abstract}
Аннотация. Целью данной работы является изучение влияния новых модифицированных ингредиентов на комплекс свойств композитных эластомерных материалов. Установлено, что введение модифицированных ингредиентов в состав эластомерных композиций усиливает межфазное взаимодействие на границе «каучук-наполнитель» и образование дополнительных связей между макромолекулами каучука и функциональными группами, в результате чего улучшается комплекс свойств композиций. Введение модифицированного углерода в состав эластомерных композиций усиливает межфазное взаимодействие на границе «каучук-наполнитель» и образование дополнительных связей между макромолекулами каучука и функциональными группами олигомера, в результате чего улучшается комплекс свойств составов. Разработана технология очистки минеральных наполнителей от оксидов металлов. Достаточно высокая степень очистки этим методом обусловлена тем, что в процессе температурного воздействия 950 К ионы железа из парамагнитного состояния (d-форма $\mathrm{Fe}_{2} \mathrm{O}_{3}$ ) переходят в ферромагнетик (r-форма $\mathrm{Fe}_{3} \mathrm{O}_{4}$ ). Возможна и перспектива использования модифицированных наполнителей, как минеральных, так и органических, в рецептурах резиновых смесей для производства различных видов резинотехнических изделий.
\end{abstract}

Ключевые слова: каучук, наполнитель, пластификатор, ускоритель, активатор, модификация.

Цитирование: Якубов, Б. Б. Исследования наполненных композиционных эластомерных материалов / Б. Б. Якубов, А. Ибадуллаев, Д. К. Якубова, Э. У. Тешабаева // Журн. Сиб. федер. ун-та. Химия, 2021, 14(4). С. 464-476. DOI: 10.17516/19982836-0255

\section{Introduction}

Thanks to fundamental research by a number of foreign and domestic scientists in the field of chemistry and technology of composite materials, significant progress has been achieved in creating them, based on flexible-rigid-chain polymers, with a wide range of properties. Meanwhile, research in the field of creating the physicochemical foundations of the technology for producing elastomeric composite materials, using ingredients that are different in nature and structure, are far from substantiated [1,2]. This requires a fundamentally new approach to creating high-quality ingredients, taking into account the specifics of their structure and properties. All this makes it possible to move

$$
-465-
$$


from empirical to scientifically grounded selection of ingredients for the production of elastomeric composite materials for various purposes.

Vulcanizing agents are chemically active compounds that take part in the formation of the spatial structure of vulcanizates. In the process of the formation of the spatial structure with an increase in the degree of crosslinking, there is a decrease in the number average $\left(\mathrm{M}_{\mathrm{n}}\right)$ of polymer chain segments and, accordingly, an increase in the number of crosslinks per unit volume of the vulcanizate (v). With a change in the degree of cross-linking, a gradual change in the properties of vulcanizates occurs. The equilibrium modulus with an increase in the density of the vulcanization network and in accordance with the molecular-kinetic theory of elasticity increases in direct proportion to the number of crosslinks or inversely proportional to the average molecular weight of the chain segments between the nodes of the spatial network of the vulcanizate. The change in hardness and strength characteristics of vulcanizates depends on many factors. So, during vulcanization of rubbers with sulfur, depending on the content of attached sulfur, and hence on the density of the vulcanization network, first, up to a content of bound sulfur of about $5 \mathrm{wt}$. including there is an increase in tensile strength of vulcanizates. This vulcanizate has the properties of soft rubber. With a further increase in the content of bound sulfur to 10 mass.h. the strength of vulcanizates decreases, the material becomes tough, leathery. If the content of bound sulfur is further increased, then the strength of the vulcanizate increases again, and it turns into hard ebonite. This is due to the fact that when a certain degree of crosslinking is reached, the distance between some nodes becomes too small as a result of uneven crosslinking, which makes it difficult to orientate molecular chains during stretching. This leads to local overvoltages, therefore, to rupture of circuits in these places. A further increase in bond strength with the transition from highly elastic to elastic deformation and strength in this case will be due to purely chemical bonds [3-6].

With an increase in the density of the vulcanization network, the relative and residual elongations decrease to very small values typical for brittle materials. In this case, the elasticity changes according to a complex relationship: the maximum elastic properties are manifested at such a density of the vulcanization net, at which the maximum strength is observed for soft rubbers. In addition, the swelling in solvents decreases in proportion to the increase in the degree of crosslinking [7,8].

To obtain rubbers with a given set of properties, it is necessary to provide a certain degree of crosslinking of elastomers by introducing a certain amount of vulcanizing substances into the composition. In this case, the number of formed cross-links will depend on the nature of the rubber, the nature and content of the vulcanizing substance, the conditions of vulcanization. Some accelerators are also curing agents. For example, thiurams and polysulfide accelerators at the vulcanization temperature can cure some rubbers without the use of elemental sulfur. The activity of most accelerators increases with the introduction of metal oxides, stearic acid, etc. Vulcanization accelerators for one type of rubber can completely lose the properties of accelerators and play a different role in compositions based on another rubber $[8,9]$.

The aim of the work is to study the effect of new modified ingredients on the complex of properties of composite elastomeric materials.

\section{Objects and research methods}

The standard rubber compound was isoprene, styrene butadiene nitrile butadiene, chloroprene rubbers. The investigated fillers were Angren kaolin, bentonite of Uzbekistan, phosphogypsum, 
wollastonite, natural burnt clay, modified carbon. Physicochemical characteristics of carboncontaining secondary raw materials were determined by: GOST 25699.1-93-sampling method; GOST 25699.2-93-specific conditional surface; GOST 25699.3-93 $3^{\text {rd }}$ iodine number; GOST 25699.4-93-specific adsorption surface; GOST 25699.5-93-oil adsorption; The total oxygen content and the content of its functional groups - lactone and quinone by pyrolysis in a stream of nitrogen, carboxyl and hydroxyl - by the method of selective neutrolization with $\mathrm{Na}_{2} \mathrm{CO}_{3}$ and $\mathrm{NaOH}$ solutions. To isolate soluble products from carbon-containing secondary raw materials, the test sample in a filter paper bag was placed in a Soxhlet apparatus and extracted for 72 hours with gasoline, acetone, benzene, and toluene. IR spectra were recorded in the form of films on KBr-20 plates in the range of 400-2000 $\mathrm{sm}^{-1}$. PMR spectra were recorded on a high-resolution NMR spectrometer on a superconducting magnet with an operating frequency for protons of $294 \mathrm{MHz}$ in $\mathrm{CCl}_{4}$ or $\mathrm{C}_{6} \mathrm{D}_{6}$ with $\left(\mathrm{CH}_{3}\right)_{4} \mathrm{Si}$ solutions as an internal standard. EPR spectra were recorded on an EPR-3 instrument at 295K. The molecular weight of the extraction products of carbon-containing secondary raw materials was determined on an EP-68 in chloroorm. The production of rubber mixtures was carried out on laboratory mixing rollers RC-WW 150/330 (Rubicon, Germany). The determination of the Mooney viscosity of rubber mixtures was carried out on a Mooney MV 2000 viscometer (Alpha Technologies, England). The stress relaxation test was carried out on the same samples as the Mooney viscosity, immediately after completing the viscosity measurement by stopping the rotor very quickly and measuring the drop in the final Mooney viscosity over time. The kinetics of vulcanization of rubber compounds was determined using an ODR2000 orheometer (Alpha Technologies, UK). Technical indicators were determined by the corresponding GOST.

\section{Results and discussion}

Based on the analysis of the data of numerous studies and experimental results, it has been established that the above-mentioned raw materials cannot be used directly in the production of rubber products without preliminary processing and appropriate chemical modifications. They contain up to $5 \%$ iron oxide and up to $30 \%$ water, which negatively affect the technological and physical and mechanical properties of elastomeric compositions and products made from them. And the main requirement for these materials is that their content is not more than $0.3 \%$. After electromagnetic separation and drying at 373-426K, the content of metal oxides decreases only to $2.2 \%$, and the amount of bound water decreases to $15 \%$ [8-12].

To increase the magnetic susceptibility of weakly magnetic metal oxides (mainly $\mathrm{Fe}_{2} \mathrm{O}_{3}$ ) and remove bound water in the composition of the investigated fillers, the method of heat treatment was used. The processing of mineral fillers was carried out for different times and temperatures, then cleaning was carried out on an electromagnetic separator. From the data in Table 1 it can be seen that in order to achieve a higher degree of purification of mineral fillers, it should be subjected to preliminary electromagnetic separation, followed by heat treatment at $\mathrm{T}=1000-1273 \mathrm{~K}$ for 60 minutes and electromagnetic cleaning. A sufficiently high degree of purification by this method is due to the fact that in the process of temperature exposure at $950 \mathrm{~K}$, iron ions from the paramagnetic state (d-form $\mathrm{Fe}_{2} \mathrm{O}_{3}$ ) pass into ferromagnetic (r-form $\mathrm{Fe}_{3} \mathrm{O}_{4}$ ) $[13,14]$.

Derivographic studies have also shown that for deep dehydration of kaolin, it is sufficient to heat the mineral at temperatures $\mathrm{T}=773-823 \mathrm{~K}$. In the case of bentonite, the removal of adsorbed water 
Table 1. Influence of time and temperature of treatments on the degree of purification of mineral fillers from metal oxides

\begin{tabular}{|c|c|c|c|c|c|c|}
\hline \multicolumn{7}{|c|}{ Content of metal oxides, $\%$} \\
\hline \multirow{2}{*}{$\begin{array}{c}\text { Before } \\
\text { electromagnetic } \\
\text { cleaning }\end{array}$} & \multirow{2}{*}{$\begin{array}{c}\text { After electro } \\
\text { magnetic cleaning }\end{array}$} & \multicolumn{5}{|c|}{ Heat treatment time, $\min$} \\
\hline & & $\begin{array}{l}\text { Sample temperature. } \\
\text { C }\end{array}$ & 20 & 40 & 60 & 80 \\
\hline \multirow{4}{*}{5,7} & \multirow{4}{*}{2,22} & 773 & 2,20 & 2,18 & 1,99 & 1,90 \\
\hline & & 973 & 2,07 & 1,91 & 1,56 & 1,50 \\
\hline & & 1173 & 1,98 & 1,02 & 0,21 & 0,20 \\
\hline & & 1373 & 1,25 & 0,98 & 0,19 & 0,19 \\
\hline
\end{tabular}

proceeds even at 363-463 K and depends on the type of cation. Removal of water and the formation of anhydrous clays occur at temperatures of 933-983 K [15].

Industrial waste phosphogypsum (PG) differs in chemical composition from traditional mineral fillers and contains mainly $\mathrm{CaSO}_{4}, \mathrm{SiO}_{2}, \mathrm{H}_{2} \mathrm{O}, \mathrm{P}_{2} \mathrm{O}_{5}$ and other oxides of alkali and alkaline earth metals $[16,17]$. According to the data of X-ray structural analysis, crystallization water is included in the composition of the crystal lattice of the PG, which is lost when it is heated above $423 \mathrm{~K}$, the maximum removal of water from the FG occurs during heat treatment at a temperature of $473 \mathrm{~K}$. Under these conditions, a structural transformation takes place simultaneously, as indicated by disappearance of lines $\mathrm{d}=5.96 ; 4.25 \AA$ and the appearance of the $\mathrm{d}=3.49 \AA$ line in the diffractogram. The latter refers to the formed anhydride. An increase in temperature to $773 \mathrm{~K}$ and above leads to a more intense appearance of lines characteristic of anhydride. In the temperature range 1073-1273 K, the PG completely transforms into the anhydride (anhydrous) state. Based on this, we have chosen the range of calcination temperature PG 1073-1273 K. Studies have shown (Table 2) that during heat treatment of such natural minerals as Angren kaolin, phosphogypsum, bentonite, wollastonite, natural clay at $1000-1273 \mathrm{~K}$ also has place of structural changes, increasing oil absorption and specific geometric surface. Using the EPR method, an increase in the concentration of free radicals was established, indicating the formation of paramagnetic centers in the samples under study. A significant difference was also found between the modified fillers in the dispersibility and distribution of particles of the

Table 2. Specific geometric surface and oil absorption of mineral fillers, depending on the conditions of heat treatment, at $1273 \mathrm{~K}$, for 60 minutes

\begin{tabular}{|c|c|c|c|c|c|c|c|c|c|c|}
\hline \multirow{3}{*}{ The name of indicators } & \multicolumn{10}{|c|}{ Indicators $^{*}$} \\
\hline & \multicolumn{5}{|c|}{ Before heat treatment } & \multicolumn{5}{|c|}{ After heat treatment } \\
\hline & B & $\mathrm{AK}$ & WL & $\mathrm{NBC}$ & $\mathrm{PG}$ & $\mathrm{MB}$ & MAK & MW & $\mathrm{MPH}$ & MPG \\
\hline $\mathrm{S}_{\text {уд }}, \mathrm{M}^{2} / \Gamma$ & 29,1 & 21,2 & 2,1 & 18,3 & 2,2 & 35,4 & 24,2 & 2,9 & 22,2 & 2,9 \\
\hline Oil absorption $\mathrm{ml} / 100 \mathrm{~g}$ : & & & & & & & & & & \\
\hline linseed & 32,0 & 21,0 & 7,48 & 21,3 & 16,4 & 34,1 & 27,0 & 9,46 & 24,5 & 17,9 \\
\hline petrolatum & 38,2 & 28,0 & 10,2 & 20,3 & 24,6 & 44,2 & 34,0 & 12,3 & 27,1 & 26,4 \\
\hline DBP & 36,4 & 25,2 & 11,9 & 18,1 & 26,2 & 43,0 & 31,5 & 14,3 & 24,3 & 27,6 \\
\hline
\end{tabular}

* Original B - bentonite, AK-Angren kaolin, WL - wollastonite, NBC-naturally burnt clay, PG-phosphogypsum, MBModified bentonite, MAK-Angren kaolin, MW-wollastonite, MPH-phosphogypsum. 
modified fillers in the elastomeric matrix, as compared to the unmodified ones. The best dispersibility and, accordingly, the highest degree of uniformity in the distribution of filler particles is characteristic of rubber mixtures filled with modified fillers [18-20].

Elastomers were studied by the method of static adsorption from dilute solutions in order to reveal the peculiarities of the interaction of macromolecules of various rubbers with particles of modified mineral fillers. It was found that modified mineral fillers have a higher adsorption activity to rubber macromolecules as compared to unmodified ones. Apparently, this effect is due to an increase in their specific surface area and concentration of active centers. It was found that modified phosphogypsum, just like chalk, exhibits low adsorption capacity; therefore, it can be concluded that these materials have the same specific surface area. It is noticed that depending on the type of elastomer, the value of the maximum adsorption value of fillers changes significantly.

As a result of the experimental studies, the following sequence of the arrangement of the studied mineral fillers in terms of adsorption activity to rubber macromolecules was established:

\section{$\mathrm{MB}>\mathrm{MAK}>\mathrm{NBC}>\mathrm{MW}>\mathrm{MPH}$}

The results of the physicochemical analysis of carbon-containing secondary raw materials (production waste) indicate (Table 3) the difference in its chemical composition from the well-known grades of low-structural technical carbons T 900, T 701, T 705, P 803, namely, with increased oxygen and hydrogen content. The study of the products of extraction of carbon-containing secondary raw materials indicate the presence of up to $12 \%$ of organic compounds, sized on the surface of carbon particles. The elemental composition was established: carbon- $92.11 \%$, hydrogen-5.70 \% and oxygen-2.19\%. The gross formula of the extract is $\mathrm{C} 54 \mathrm{H} 40 \mathrm{O}$. The number average molecular weight according to gel chromatography data is $\approx 700$. IR spectroscopic studies show that the extraction products are combinations of condensed aromatic and paraffinonaphthenic hydrocarbons, as well as oxygen-containing carbonyl compounds. This, in particular, is indicated by the appearance of characteristic absorption bands in the region of $3050 \mathrm{~cm}-1$ (stretching vibrations of C-H bonds of the aromatic ring), 2860, 2930 and $2975 \mathrm{~cm}-1$ (stretching vibrations of C-H bonds of methylene and methyl groups). Absorption bands are also found at $1710 \mathrm{~cm}-1$ (carbonyl group $\mathrm{C}=0$ ) in the carbon chain, and in asphaltene resins at $1730 \mathrm{~cm}-1$. The absorption bands in the region of $1500-1600 \mathrm{~cm}-1$ correspond to stretching vibrations of $\mathrm{C}=\mathrm{C}$ - bonds, which are products of thermal cyclization and oligomerization of acetylene. Obtaining PMR spectra, in turn, indicate the presence of protons at $\mathrm{d}=6.70 \mathrm{ppm}, \mathrm{d}=6.85 \mathrm{ppm}, \mathrm{d}=7.10 \mathrm{ppm}$, characteristic of aromatic structures and its substituted derivatives.

The extracted product gives a narrow single EPR signal with a PMC concentration of $1 \times 10^{14} \mathrm{spin}$ / g., $\mathrm{g}$ is a factor close to the $\mathrm{g}$ factor of a free electron. It should be noted that the results of the mass spectrometric study also confirmed the proposed composition of the extract products. Studies have shown that the carbon-containing secondary raw material is modified carbon, the surface of which is microencapsulated with oligomeric oxygen-containing compounds. The thickness of the oligomeric cover, calculated from the value of the specific geometric surface, was about 50-60 E. The modified carbon is characterized by an increased value of the oil and iodine numbers, which is associated with the surface roughness $(\mathrm{Sc}=25-30 \mathrm{~m} 2 / \mathrm{g})$ and the presence of polyconjugated systems. In addition, we note that it is characterized by a high degree of dispersion.

$$
-469-
$$


Table 3. Elemental composition of MC and some grades of carbon black

\begin{tabular}{|c|c|c|c|c|c|}
\hline \multirow{2}{*}{ The name of indicators } & \multicolumn{5}{|c|}{ Content, $\%$} \\
\cline { 2 - 6 } & $\mathrm{MC}^{*}$ & $\mathrm{~T} 900$ & $\mathrm{~T} 701$ & $\mathrm{~T} 705$ & $\Pi 803$ \\
\hline Carbon & $88-90$ & $96-99$ & $96-98$ & $96-98$ & $97-99$ \\
\hline Hydrogen & $3-4$ & $0,3-0,5$ & $0,4-0,6$ & $0,6-0,8$ & $0,4-0,6$ \\
\hline Oxygen & $6-7$ & $0,1-0,2$ & $0,3-0,5$ & $0,3-0,5$ & $0,1-0,2$ \\
\hline Sulfur & - & 0,1 & 0,3 & 0,3 & 0,2 \\
\hline Ash content & $0,8-0,9$ & $0,1-0,2$ & $0,4-0,6$ & $0,4-0,5$ & $0,4-0,5$ \\
\hline
\end{tabular}

*MC-modified carbon.

Electron microscopic studies indicate that the structure of the modified carbon particles is somewhat different from the particles of the original technical carbon, there are no clear boundaries of the spheroidal shape of particles characteristic of carbon black. However, after heat treatment at $1573 \mathrm{~K}$ for 1 hour (in a nitrogen atmosphere), its structure approaches the structure of carbon black, and the average surface particle diameter decreases from 30.6 to $21.5 \mathrm{~nm}$. An increase in the specific geometric surface from 20.3 to $29.3 \mathrm{~m} 2 / \mathrm{g}$ is observed. The latter is probably due to the process of dispersion of larger particles due to the volatilization of moisture and other accompanying substances during heat treatment.

Comparing the results of X-ray studies of the initial and heat-treated modified carbon, it was found that they are characterized by the presence of an insignificant impurity of crystalline phases. These phases, apparently, refer to hydrocarbons contained in its composition (up to $12 \%$ ). The main phase of modified carbon is a phase with a typical turbostratic structure (packing of structural elementgraphite-like), which is proved by the characteristic asymmetric profile of diffraction fringes. The diffractograms of modified carbon, in contrast to the diffractogram of carbon black, are characterized by a rather low ordering of the turbostratic layers of layers, as evidenced by the value of $\mathrm{J}_{002} / \mathrm{J}_{002}$. It should be noted that the interplanar spacings $\left(\mathrm{d}_{002}\right)$ for carbon black are significantly lower. The degree of ordering of the modified carbon (parameter $\mathrm{J}_{002} / \mathrm{J}_{002}$ ) increases with high-temperature (973-1573 $\mathrm{K})$ treatment. The sizes of the areas of coherent distance of amorphous phases are determined, the height is $12-0.5 \AA$, the size of the layers varies within $15-20 \AA$. The conducted studies suggest that the structure of modified carbon seems to be an intermediate stage in the formation of soot structures. It can be assumed that the use of a carbon filler finished with an oligomer coating, consisting of a conjugation system, makes it possible to formulate a fundamentally new approach for creating filled elastomeric compositions with improved properties.

It was found that the introduction of modified carbon into the composition of elastomeric compositions increases the carbon content of the rubber gel, the density of the mesh, the stress deformation of rubbers, and the degree of swelling of the sample decreases. This is due to the presence of oligomer components, especially on the surface of carbon particles. In order to clarify the nature of the influence of oligomer fractions on the process of structure formation of rubbers, the modified carbon was subjected to selective extraction and carbon black P 803 was modified with the obtained oligomer. The introduction of modified carbon black P 803 into rubber compounds leads to an increase in the content of carbon rubber gel (CRG) and an increase in stress (E300) with an increase in the density of the mesh and a decrease in the swelling of elastomeric compositions. Presumably, this is due 
to: firstly, with an increase in the adsorption interaction of modified carbon black P 803 with rubbers, and secondly, the formation of additional bonds between rubber macromolecules and functional groups of the oligomer, confirmed by IRS, DTA, and TGA data.

Thus, we can assume that the introduction of modified carbon into the composition of elastomeric compositions enhances interfacial interaction at the rubber-filler interface and the formation of additional bonds between rubber macromolecules and functional groups of the oligomer, as a result of which an improvement in the complex of properties of the compositions is observed.

Physicochemical properties of fillers significantly affect the basic technological and physical and mechanical properties of elastomeric compositions. When studying the process of mixing rubbers of various nature with modified fillers (MB, MV, MAK, NBC, MU and MFG), the distinctive behavior of these fillers in non-crystallizing rubbers SKMS-30RP and SKN-18 was established. It is noted that in the process of mixing SKMS-30RP rubber with 100 wt.h. MAC, 60 parts by weight MB, 80 parts by weight GLEE and 60 wt.h. MV appears on the plastogram a second maximum, depending on the mixing time: $\varphi=14-16,16-18,13-14$ and $14-15$ minutes, respectively. In the case of 50 wt.h. MU SKN-18 maximum is observed at $\mathrm{f}=6-9$ minutes, which is associated with the end of the process of dispersion of fillers and the formation of a homogeneous mixture. The appearance of this effect is due to the manifestation of special interactions at the rubber-filler interface (Fig. 1).

It is shown that the increased rubbing and absorption in the elastomer of the studied modified fillers in comparison with unmodified and commercially used fillers, which are characterized by lower values of the amplitude of torque oscillations. This, in turn, leads to better workability and plasticity of rubber compounds. It was found that this circumstance is due to the physicochemical, structural features of the modified mineral fillers, and in the case of modified carbon, the presence of an intermediate oligomeric layer that plays the role of a sizing agent. In favor of this assumption, a

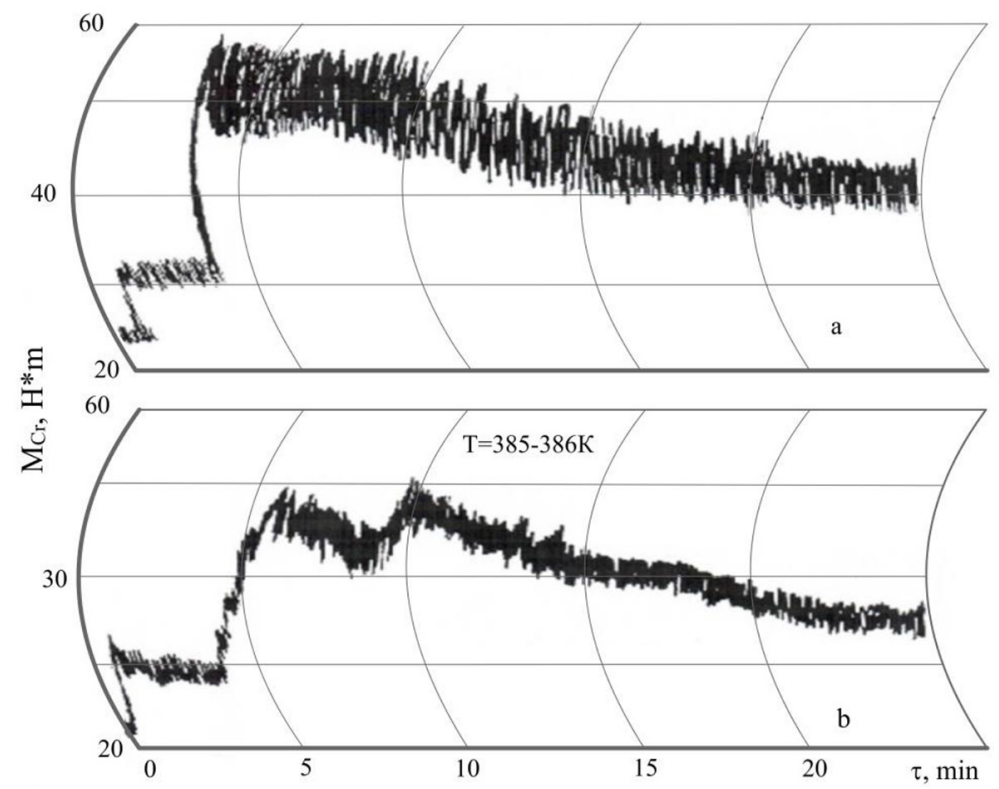

Fig. 1. Plastograms of the kinetics of the change in torque in time during the displacement $\left(\mathrm{D}_{\mathrm{Dis}}\right)$ of 40 wt.h. IB (a) and MOB (b) per 100 wt.h. rubber SKMS-Z0ARP 
decrease in the time and temperature of mixing elastomeric compositions filled with modified fillers is indicated in comparison with unmodified and commercially used ones.

The study of the rheological properties of filled elastomeric compositions showed that the lower the shear stress (Ũ), the greater the manifestation of the effect of the filler on the effective viscosity (EE) of the mixture. At the same time, the introduction of modified mineral fillers into the composition of the elastomer leads to an increase in the ZE of rubber compounds as they are filled. This is especially true in the case of highly dispersed bentonite and Angren kaolin.

The values of the apparent activation energy (E) of the viscous flow of elastomers filled with the investigated fillers were determined. A significant difference was found in the behavior of modified bentonite and Angren kaolin in non-crystallizing rubber SKMS-30RP, characterized by a high value of E viscous flow ( 64.3 and $56.6 \mathrm{~kJ} / \mathrm{mol}$ ). For comparison, we can note the system containing the original bentonite and Angren kaolin (42.7 and $40.8 \mathrm{~kJ} / \mathrm{mol}$ ). This behavior of modified bentonite and Angren kaolin is possibly related to structural features, as well as more efficient interaction at the rubber-filler interface.

It was found that with an increase in the filler content in the rubber, the recoverability of the rubber mixture after deformation significantly decreases. At the same time, the ability of the system to accumulate the energy of elastic deformation, i. e. swelling of the extrudate (Pe), largely depends on the specific geometric surface (Ssp) of the fillers. So, for example: when filling the rubber with $60 \mathrm{wt} . \mathrm{h}$. with modified bentonite, Angren kaolin and phosphogypsum, the swelling of the extrudate (Re) from unfilled rubber is reduced by 545, 510 and $250 \%$ (for SKI-3); 360, 325, and $310 \%$ (for KR-50 nairite), respectively. The ability of the system to accumulate the energy of elastic deformations decreases with an increase in the content of the filler according to the value, its Ssp. According to the influence of the rheological properties of elastomeric compositions, the fillers studied by us, in accordance with the values of $\mathrm{E}$, and $\mathrm{Re}$, can be arranged in the following row:

$$
\mathrm{MB}>\mathrm{MAK}>\mathrm{NBC}>\mathrm{MC}>\mathrm{MPH}
$$

Plasto-elastic properties of filled rubber compounds with modified fillers have shown that in terms of their technological parameters, they practically do not differ from commercially used mineral fillers. However, at high degrees (more than 30 parts by weight per 100 parts by weight) of rubber filling, it will be necessary to take into account the specific surface area of modified bentonite, Angren kaolin and natural burnt clay, which contributes to a more significant increase in the effective viscosity of rubber compounds.

It has been established that the introduction of modified carbon and natural burnt clay into the composition of the composition increases the confection stickiness of rubber mixtures, in comparison with carbon black P803 and EK. For example, when filling 50 wt.h. rubbers SKI-3, Nairite KR-50, SKMS-30RP and SKN-18 MU and NBC; the confection stickiness of rubber mixtures is 2.15 and 1.86 $\mathrm{kN} / \mathrm{m}: 1.60$ and $1.12 \mathrm{kN} / \mathrm{m} ; 2.20$ and $1.81 \mathrm{kN} / \mathrm{m} ; 1.40$ and $1.21 \mathrm{kN} / \mathrm{m}$, respectively. It is noticed that in the case of using phosphogypsum as a filler, in the formulations of rubber compounds, it manifests itself as very inert, similar to chalk.

In the case of modified carbon, this effect increases with an increase in its content, and vulcanizates are characterized by higher tensile strength (Fp), compared to rubber containing P803 carbon black. So, for example, with a content of 40 wt.h. MU and carbon black P803 in the composition of elastomeric 

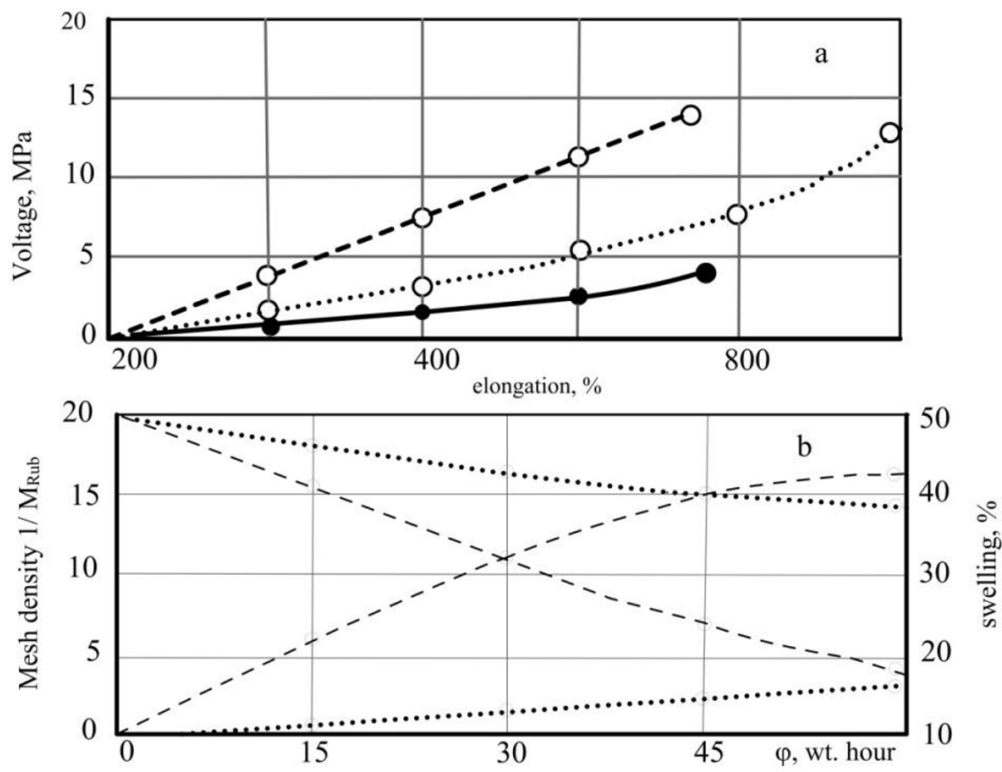

Fig. 2. Dependence of the conditional stress on the elongation of rubbers (filler content 40 parts by weight per 100 parts by weight of rubber) -a, swelling and mesh density of composites-b based on SKMS-30ARP rubber. IB $(--)$ and $\mathrm{MOB}($

compositions based on SKI-3, nairite KR-50, SKMS-30RP and SKN-18, Fr values are 21.5 and 17.5; $12.6 \& 9.7 ; 13.1 \& 10.1 ; 15.2$ and $12.9 \mathrm{MPa}$, respectively. Obviously, this is due to the presence of an oligomeric cover on the surface of carbon particles, which enhances the effect of the interaction of the rubber-filler. This is evidenced by a decrease in the conditional stress during elongation of rubbers containing heat-treated modified carbon. It has been established that the introduction of modified fillers into compositions significantly increases the resistance of rubbers to tearing in comparison with commercially used fillers. This is especially pronounced when the content is $60-70$ wt.h. modified fillers per 100 wt.h. rubber SKMS-30RP, i. e. tear resistance increases from 42.6 to $74.2 \mathrm{kN} / \mathrm{m}$.

The study of the effect of modified fillers on the dynamic properties of rubbers under repeated compression showed that when they are introduced into the composition of the compositions, a decrease in heat generation and permanent deformation is observed. They also affect the dynamic durability of rubbers under repeated stretching (Nras). In compositions based on rubbers, Nairite KR-50, SKMS-30RP and SKN-18 Nrac passes through a maximum and its greatest value is observed at a content of 40-60 wt.h. per 100 wt.h. rubber. It was shown that the combination of the studied modified fillers with carbon blacks (P324, K354, etc.) also gives a certain effect. So, with an increase in the content of modified carbon, when combined with a mineral filler, the elastic-strength properties of vulcanizates increase. This process can be controlled and purposefully improved a number of technological and technical parameters of elastomeric compositions. In this case, special attention should be paid to the degree of filling and the ratio of the modified filler and carbon black.

The study of the effect of modified fillers on the dynamic properties of rubbers under repeated compression showed that when they are introduced into the composition of the compositions, a decrease in heat generation and permanent deformation is observed. They also affect the dynamic durability of rubbers under repeated stretching (Nras). In compositions based on rubbers, Nairite 
Table 4. Influence of the proposed modified bentonite performance properties of rubber-textile and metal-frame products

\begin{tabular}{|c|c|c|c|c|}
\hline \multirow{2}{*}{ Indicators } & \multicolumn{2}{|c|}{$\begin{array}{l}\text { Rubber textile products } \\
\text { № } 9101\end{array}$} & \multicolumn{2}{|c|}{$\begin{array}{l}\text { Metal frame products } \\
\text { № } 922\end{array}$} \\
\hline & $\begin{array}{c}\text { Standard } \\
\text { composition }\end{array}$ & $\begin{array}{c}\text { Suggested } \\
\text { composition }\end{array}$ & $\begin{array}{c}\text { Standard } \\
\text { composition }\end{array}$ & $\begin{array}{l}\text { Suggested } \\
\text { composition }\end{array}$ \\
\hline $\mathrm{P}$, conven. unit. & $0,35-0,40$ & 0,40 & $0,35-0,40$ & $\mathbf{0 , 4 0}$ \\
\hline $\mathrm{F}_{\mathrm{r}}, \mathrm{MPa}$ & $9,2-10,2$ & 15,6 & $3,0-4,0$ & 9,3 \\
\hline $\mathrm{E}_{\text {relatively }} \%$ & $300-350$ & 320 & $200-250$ & 220 \\
\hline $\mathrm{F}_{\text {making }} \%$ & $8-10$ & 6 & $4-6$ & 4 \\
\hline $\mathrm{P}_{\mathrm{a}}, \mathrm{kN} / \mathrm{m}$ & $40-45$ & 68 & $40-50$ & 59 \\
\hline Stickiness (BN-5006, rbr 1,5), kg. & $1,0-1,5$ & 1,8 & $1,2-1,6$ & 1,6 \\
\hline Adhesion strength, $\mathrm{MPa}$ & $0,70-0,80$ & 0,92 & $0,7-0,8$ & 1,10 \\
\hline
\end{tabular}

KR-50, SKMS-30RP and SKN-18 Nrac passes through a maximum and its greatest value is observed at a content of $40-60$ wt.h. per 100 wt.h. rubber.

Table 4 shows the operational properties of production formulations for obtaining textile and metal frame products using modified bentonite. As can be seen from the table, the technological and physical and mechanical properties of the composition are much higher than the required standard indicators. This shows, firstly, that modified bentonite can replace standard ingredients, and secondly, the dispersion of the modified bentonite creates a colloidal disperse system together with elastomers ensures their uniform distribution throughout the composition.

It was shown that the combination of the studied modified fillers with carbon blacks (P324, $\mathrm{K} 354$, etc.) also gives a certain effect. So, with an increase in the content of modified carbon, when combined with a mineral filler, the elastic-strength properties of vulcanizates increase. This process can be controlled and purposefully improved a number of technological and technical parameters of elastomeric compositions. In this case, special attention should be paid to the degree of filling and the ratio of the modified filler and carbon black

\section{Conclusion}

The technology of purification of mineral fillers from metal oxides has been developed. A sufficiently high degree of purification by this method is due to the fact that in the process of temperature exposure at $950 \mathrm{~K}$, iron ions from the paramagnetic state (d-form $\mathrm{Fe}_{2} \mathrm{O}_{3}$ ) pass into ferromagnetic ( $\mathrm{r}$ form $\mathrm{Fe}_{3} \mathrm{O}_{4}$ ). Feasibility and prospects of the use of modified fillers, both mineral and organic, in the formulations of rubber compounds for the production of various types of rubber products.

\section{References}

1. Primeneniye rezinovykh tekhnicheskikh izdeliy v narodnom khozyaystve. Spravochnoye posobiye. The use of rubber technical products in the national economy. Reference manual. Moscow, 1996, Khimiya, 378 p.

2. Negmatov N.S., Ziyamukhamedova, U.A., Kuluev, A.R. Antifriction materials and water-soluble compounds on basis of polymers for reducing the mechanical damage of cotton fibers. Plastics: Synthesis Properties Recycling Applications 2002. Vol. 1, P. 42-45. 
3. Umarov, A., Kamalova, D., Investigation of ultrafine expansion in Epr studies of a polymer composition based on polystyrene. AIP Conference Proceedings 2020, 2308, 030019.

4. Liu Y., Wang W., Wang A., Jin Z., Zhao H., Yang Y. Effect of vapor pressure on performance of sulfurized polyacrylonitrile cathodes for Li/S batteries. RSC Advances. 2016. Vol. 6, P. 625-630.

Available at: https://pubs.rsc.org/en/content/articlelanding/2016/ra/c6ra24443b\#!divAbstract

5. Bukit N., Ginting E. M., Pardede I. S., Frida E., Bukit B. F., Mechanical properties of composite thermoplastic hdpe natural rubber and palm oil boiler ash as a filler. The open access Journal of Physics 2018. Vol. 1120, P. 1-8. doi: 10.1088/1742-6596/1120/1/012003.

6. Miradullaeva, G., Rakhmatov, E., Bozorov, O., Ziyamukhamedova, U., Shodiev, B. Mathematical modeling of rheological properties during structure formation of heterocomposite potting materials and coatings and their application. Lecture Notes in Civil Engineering 2021. Vol. 150, P. 346-355.

7. E.M. Ginting, N. Bukit, GultomD. Motlan, E. Frida, B.F. Bukit, Preparation and characterization of oil palm empty bunches powder as A filler of polypropylene natural rubber, International Journal Civil Engineering Technology 2019. Vol. 10(6), P. 453-464.

8. Myint N.N., Aye T.T., Naing K.M., Wynn N. Performance study of the natural rubber composite with clay minerals. Myanmar Academy of Arts and Science. 2008, Vol. 1(6), P. 151-159.

9. Ziyamukhamedova U., Djumabaev D., Shaymardanov B. Mechanic chemical modification meth od used in the development of new composite materials based on epoxy binder and natural min erals. Turkey. Turkish Journal of Chemistry, 2013. Vol. 37(1), P. 51-56.

10. Phrommedetch S., Pattamaprom C., Compatibility improvement of rice husk and bagasse ashes with natural rubber by molten-state maleation, European Journal of Scientific Research. 2010. Vol. 43(3), P. 411-416.

11. Bukit N., Frida E., The effect zeolite addition in natural rubber polypropylene composite on mechanical, structure, and thermal characteristics, Makara. Journal Technology, 2013. Vol. 27(3), P. $113-130$.

11. Ибадуллаев А., Негматов С.С., Хайдаров И.Ю., Тешабаева Э. У. Влияние дисперсных наполнителей на вязкоупругие свойства невулканизованных эластомеров. Композиционные материалы 2003. Т. 2, С. 5-7. [Ibadullaev A., Negmatov S. S., Xaydarov I.YU., Teshabaeva E.U. [Influence of dispersed fillers on the viscoelastic properties of uncured elastomers. Composite materials, 2003. Vol. 2, P. 5-7. (In Russ.)]

12. Ibadullayev A., Muftullaeva M.B. Study of adsorption properties of montmorillonite of Karakalpakstan. Austrian Journal of Technical and Natural Sciences 2019. Vol. 7(8), P. 57-63.

13. Ibadullayev A., Muftullaeva M. B. Study of physic-chemical properties of montmorillonite of Karakalpakstan. Nukus, Science and education in Karakalpakstan 2019. Vol. 4, P. 10-14.

14. Тешабаева Э.У., Ибадуллаев А., Жураев В.Н. Создание и применение ингредиентов на основе местных сырьевых ресурсов и отходов производств в эластомерных композиционных материалах. Химия и химическая технология 2016. С. 66-71. [Teshabaeva E.U., Ibadullaev A., Juraev V.N. Creation and application of ingredients based on local raw materials and production waste in elastomeric composites. Chemistry and chemical technology 2016, P. 66-71. (In Russ.)]

15. Негматов С.С., Тешабаева Э.У., Ибадуллаев А., Таджиева Г.С., Носирова Л.Т. Исследование влияния кизылгии на кинетику вулканизации резиновых смесей на основе 
каучуков общего и специального назначения. Композиционные материаль 2004. Vol. 4, Р. 45. [Negmatov S. S., Teshabaeva E. U., Ibadullaev U., Tadjibaeva G. S., Nosirova L. T. Investigation of the effect of kizilgia on the kinetics of vulcanization of rubber compounds based on rubbers for general and special purposes. Composite materials, 2004. Vol. 4, P. 45. (In Russ.)]

16. Ибадуллаев А. Изучение влияние монтмориллонита Каракалпакстана на технологические свойства эластомерных композиций. Композищионные материалы 2019. T. 3, C. 8-14. [Ibadullaev A. Study of the influence of montmorillonite of Karakalpakstan on the technological properties of elastomeric compositions. Composite materials, 2019. Vol. 3, P. 8-14. (In Russ)]

17. Негматов С.С., Ибадуллаев А. Исследование и разработка способов совершенствования основных этапов технологии получения высокодисперсных высокоэффективных ингредиентов местного сырья. Композиционные материаль 2003. Т. 1, С. 53-54. [Negmatov S. S., Ibadullaev A. Research and development of ways to improve the main stages of technology for obtaining finedispersed highly effective ingredients based on local origin. Composite materials 2003. Vol. 1, P. 5354. (In Russ.)]

18. Ибадуллаев А., Таджибаева Г.С., Тешабаева Э.У., Негматов С.С. Исследование технологических свойств эластомерных композиций с наполнителем кызылгия. Композииионные материаль 2004. T. 1, С. 62. [Ibadullaev A., Tadjibaeva G. S., Teshabaeva E.U., Negmatov S.S. Study of the technological properties of elastomeric compositions filled with kyzylzhiya. Composite materials 2004. Vol. 1, P. 62. (In Russ.)]

19. Негматов С.С., Ибадуллаев А., Джубаев А.Б. Механохимическая активация эффективный метод улучшения эксплуатационных свойств и долговечности композитного материала. Композиционные материаль 2003. Т. 3, С. 47-48. [Negmatov S. S., Ibadullaev A., Djubaev A.B. Mechanochemical activation is an effective method for improving the performance properties and durability of composite material. Composite materials 2003. Vol. 3, P. 47-48. (In Russ.)]

20. Юсупов А.М., Ибадуллаев А., Негматов С.С., Таджибаева Г. С. Усиление эластомеров со структурно химическим модифицированным бентонитом. Композиционные материальл 2001. T. 2, C. 47-50. [Yusupov A. M., Ibadullaev A., Negmatov S. S., Tadjibaeva G. S. Strengthening elastomers with structurally chemically modified bentonite. Composite materials 2001. Vol. 2, P. 4750. (In Russ.)] 